\title{
Profile of reslizumab in eosinophilic disease and its potential in the treatment of poorly controlled eosinophilic asthma
}

This article was published in the following Dove Press journal:

Biologics:Targets and Therapy

8 January 2013

Number of times this article has been viewed

\section{Garry M Walsh}

Division of Applied Medicine, School of Medicine and Dentistry, Institute of Medical Sciences, University of Aberdeen, Aberdeen, UK
Correspondence: Garry M Walsh Division of Applied Medicine, School of Medicine and Dentistry, Institute of Medical Sciences, University of Aberdeen, Foresterhill, Aberdeen, AB25 2ZD, UK Tel +44I224437354

Email g.m.walsh@abdn.ac.uk
Abstract: Eosinophils are important proinflammatory cells that make a major contribution to the inflammation seen in allergic diseases including asthma. Interleukin-5 is central to eosinophil maturation, release from the bone marrow, and subsequent accumulation, activation, and persistence in the tissues. Reslizumab (Cinquil ${ }^{\mathrm{TM}}$ ) is a humanized monoclonal antibody with potent interleukin-5 neutralizing effects, which represents a potential treatment for poorly controlled eosinophilic asthma. This review will consider the current status of the clinical development of reslizumab for asthma and in other inflammatory diseases with a marked eosinophilic component.

Keywords: IL-5, asthma, eosinophil

\section{Introduction}

Eosinophil involvement in inflammatory conditions affecting the skin, gastrointestinal tract, and upper and lower airways is well documented. ${ }^{1}$ Eosinophilic asthma is a phenotype of the condition characterized by increased blood or sputum eosinophils whose numbers correlate with disease severity. ${ }^{2}$ Infiltrating tissue eosinophils release their potent proinflammatory arsenal including granule-derived basic proteins, lipid mediators, cytokines, and chemokines. These contribute to airway inflammation and lung tissue remodeling that includes airway thickening, fibrosis, and angiogenesis. ${ }^{3}$ More recent evidence suggests that in addition to their role as degranulating effector cells, eosinophils have the capacity to act as antigen presenting cells resulting in $\mathrm{T}$ cell proliferation and activation. ${ }^{4}$ The crucial role of interleukin (IL)-5 in the development and release of eosinophils from the bone marrow, their enhanced adhesion to endothelial cells lining the post-capillary venules, their activation, secretion, and prolonged survival through apoptosis inhibition in the tissues has been known for many years. ${ }^{5,6}$ IL-5 was therefore identified as a promising target to prevent or blunt eosinophil-mediated inflammation in patients with asthma and other eosinophil-related conditions, leading to the development of humanized anti-IL-5 monoclonal antibodies (mAb) such as mepolizumab and reslizumab or benralizumab, a mAb against human IL-5R $\alpha .^{7-10}$

Several early clinical trials in patients with mild to severe asthma that examined the effects of the anti-IL-5 mAb mepolizumab reported significant depletion of blood and sputum eosinophils. However, clinical outcomes were disappointing as there were no significant effects on airway hyperreactivity or the late asthmatic reaction to inhaled allergen challenge. ${ }^{11-14}$ It is important to note that these studies all used subjects recruited on the basis of clinical and physiological characteristics not associated with the presence 
of eosinophilic airway inflammation. ${ }^{15}$ Furthermore, IL-5 is not the sole factor responsible for eosinophil accumulation, persistence, secretion, and other activities in tissues. Other factors likely to make important contributions to these processes include granulocyte macrophage colony-stimulating factor, IL-3, IL-9, and IL-13. ${ }^{16}$

It is now appreciated that the pathophysiological asthma phenotypes need to be determined prior to the selection of patients for biologic therapy in asthma. Such an approach is supported by two more recent studies in highly selected asthma patient populations with a demonstrable sputum eosinophilia. These studies revealed that mepolizumab treatment not only reduced eosinophil numbers in the blood and sputum but also significantly reduced asthma exacerbations together with the demonstration that mepolizumab attenuated aspects of eosinophil-induced airway inflammation refractive to glucocorticoid therapy. ${ }^{17,18}$ These are important observations as they strongly support the development of discriminatory biomarkers and genetic profiling to identify patients with particular subphenotypes of asthma to guide anticytokine therapy targeting to those most likely to exhibit clinically beneficial effects.

\section{Reslizumab: synthesis and preclinical development}

Reslizumab (Cinquil ${ }^{\mathrm{TM}}$; Teva Pharmaceutical Industries Ltd, Petach Tikva, Israel [formerly SCH-55700]) was humanized from an anti-IL-5 antibody (JES1-39D10), originally raised in rats, and exhibited an extremely long duration of action in mice, monkeys, and guinea pigs. ${ }^{19,20}$ Reslizumab was synthesized by complementarity-determining region grafting of 39D10 to produce a humanized $\operatorname{IgG} 4 / \kappa$ antibody with high affinity for human IL-5, with a dissociation constant of $81 \mathrm{pM}$, and an association rate constant of $4.9 \times 10^{5} \mathrm{per} \mathrm{M} / \mathrm{s}$. Proliferation of human erythroleukemia cells induced by IL-5 was inhibited by reslizumab with an EC50 value of $45 \mathrm{pM}$. Reslizumab was evaluated in a number of animal models that feature eosinophilic inflammation. ${ }^{21}$ For example, pulmonary eosinophilia in allergic mice and Ascaris-responsive monkeys was inhibited by a single dose of reslizumab $(1 \mathrm{mg} / \mathrm{kg}$ intraperitoneally, and $0.3 \mathrm{mg} / \mathrm{kg}$ intravenously, respectively). The effect of reslizumab was sustained for 6 months after administration in monkeys, with $75 \%$ inhibition of eosinophil accumulation in response to Ascaris challenge observed. ${ }^{22}$ In an ovalbumin-sensitized guinea pig model, intravenous reslizumab $(0.03 \mathrm{mg} / \mathrm{kg}, 1 \mathrm{mg} / \mathrm{kg}$, and $30 \mathrm{mg} / \mathrm{kg})$ administered 2 hours before the ovalbumin challenge reduced eosinophilia, airway hyperreactivity, and bronchoconstriction. In a similar model that used ovalbumin-sensitized rabbits, intravenous reslizumab ( $5 \mathrm{mg} / \mathrm{kg}$ intravenously) administered 2 hours before the ovalbumin challenge reduced eosinophil influx into the skin, but did not affect the total number of cells and neutrophils in the skin. ${ }^{20}$

\section{Clinical development}

\section{Asthma}

In an early clinical trial in patients with severe asthma whose symptoms were not controlled by inhaled corticosteroids, treatment with reslizumab did not result in significant improvements in asthma symptoms or lung function, although there was a profound reduction in circulating eosinophils. Reslizumab exhibited a terminal half-life of approximately 25 days in asthmatic patients with doses of $0.3 \mathrm{mg} / \mathrm{kg}$ or greater, giving rapid decreases in peripheral blood eosinophilia. Maximal effect on the latter was observed at a dose of $1.0 \mathrm{mg} / \mathrm{kg}$ that was sustained for at least 4 weeks after administration with a return to baseline values within 5 to 6 months after the dose. ${ }^{12} \mathrm{~A}$ recent Phase II, randomized, placebo-controlled, multicenter trial evaluated intravenous reslizumab in patients with poorly controlled asthma who exhibited a sputum eosinophilia greater than $3 \%$ and whose symptoms were not controlled by a high-dose inhaled glucocorticoid. Compared with placebo $(n=53)$, the reslizumab group $(\mathrm{n}=53 ; 3.0 \mathrm{mg} / \mathrm{kg})$ exhibited a significant decrease in sputum eosinophilia together with a modest (reslizumab, -0.7 ; placebo, -0.3 ) but nonsignificant $(P=0.054)$ improvement in asthma control as assessed by the Asthma Control Questionnaire score, the primary study endpoint. In patients with concomitant nasal polyposis, a hallmark of eosinophilic disease in patients with asthma, ${ }^{23}$ reslizumab treatment was associated with a significant improvement in asthma symptoms (reslizumab, -1.0 ; placebo, $-0.1 ; P=0.012$ ). There was a nonsignificant reduction in asthma exacerbations in the reslizumab group while the adverse event profile for reslizumab and placebo were similar without evidence of rebound eosinophilia. ${ }^{24}$ These findings have led to the instigation of several asthma Phase III clinical trials of reslizumab, and these are currently underway. ${ }^{25}$

\section{Eosinophilic esophagitis}

Eosinophilic esophagitis (EE) is a relatively newly recognized severe inflammatory condition of the esophagus that is often linked with gastroesophageal reflux disease and a marked association with allergic disease. There is a strong (70\%) gender predisposition for males. Symptoms are difficult to treat and include problems with swallowing, food impaction, 
vomiting, chest pain, tissue remodeling, and stricture formation. ${ }^{26}$ Eosinophils are absent from the healthy esophagus, and EE is characterized by a marked mucosal eosinophil accumulation with a count of more than 15 cells per high power field, which is considered diagnostic for this condition. $\mathrm{EE}$ is widely seen as an idiopathic condition, reflecting the rather poor understanding of the underlying pathogenic mechanisms. ${ }^{27}$ It is thought that a marked Th2-driven component in response to both food and environmental allergens drives the accumulation of eosinophils in the esophageal mucosa. However, it is clear that this is a complex disease with major contributions also made by genetic predisposition, environmental exposure, allergen sensitization, together with the involvement of other cells and mediators in addition to eosinophils. ${ }^{28}$ Clinical studies have demonstrated increased levels of IL-5 messenger ribonucleic acid in tissue samples from patients with EE compared to control subjects. Furthermore, intracellular IL-5 levels were elevated in peripheral blood CD4-positive T cells of EE patients compared to control subjects. ${ }^{29}$ Anti-IL-5 therapy may therefore have inhibitory effects on eosinophil trafficking and survival with a positive local effect in the esophagus.

A recent double-blind placebo-controlled trial examined the effect of reslizumab treatment in 226 children or adolescents with long standing EE symptoms and significant esophageal eosinophilia. ${ }^{30}$ Patients received $1 \mathrm{mg} / \mathrm{kg}$, $2 \mathrm{mg} / \mathrm{kg}$, or $3 \mathrm{mg} / \mathrm{kg}$ of intravenous reslizumab or placebo approximately every 28 days for a total of four doses. The primary endpoint was improvement of clinical signs and symptoms and a reduction of eosinophil count. Patients treated with reslizumab had statistically significant and clinically relevant reductions in esophageal intraepithelial eosinophil counts compared with the placebo group. However, these reductions were not accompanied by significant differences between the reslizumab and placebo groups in assessments of clinical symptoms and quality of life..$^{30}$ These findings are suggestive that other proinflammatory cells, such as mast cells, may drive disease activity such that eosinophil deletion does not result in the expected reduction in symptoms. The authors also pointed out that monitoring of subjects in the clinical trial setting would have led to greater adherence to exclusion diets of known food triggers leading to clinical improvement in the placebo group. ${ }^{30}$

It should also be remembered that other mediators are potent attractants for eosinophils. For example, eotaxin-3 is a potent chemotactic chemokine for eosinophils, and a gene polymorphism for eotaxin-3 has been shown to be associated with EE. ${ }^{31}$ Moreover, IL-5 responses of tissue eosinophils may be inhibited as bronchoalveolar lavage-derived eosinophils from asthmatic subjects, ${ }^{32,33}$ or those present in nasal polyp (NP) tissue, ${ }^{34}$ exhibit downregulation of the membrane-anchored IL-5R $\alpha$ isoform, while the antagonistic soluble IL-5R $\alpha$ variant is upregulated compared with levels seen in peripheral blood.

\section{Nasal polyposis}

Bilateral NPs are often present in patients with chronic rhinosinusitis, the latter condition is frequently associated with asthma. NPs are characterized by an abundance of eosinophils in more than $80 \%$ of cases. This has raised the possibility of a role for anti-IL- 5 treatment for this condition. A double-blind, placebo-controlled, randomized, two-center safety and pharmacokinetic study investigated the effect of a single intravenous dose of reslizumab $(3 \mathrm{mg} / \mathrm{kg}$ or $1 \mathrm{mg} / \mathrm{kg}$ ) on 24 subjects with bilateral NPs. Reslizumab treatment reduced eosinophil numbers in peripheral blood together with eosinophil cationic protein concentrations in nasal secretions for up to 8 weeks after treatment. However, significant reductions in individual NP size only occurred in half of the treated patients with responder patients exhibiting increased IL-5 concentrations ( $>40 \mathrm{pg} / \mathrm{mL})$ in nasal secretions at baseline compared with nonresponders. ${ }^{35}$ The authors concluded that the selection of appropriate NP patients on the basis of IL-5 in their nasal secretions is an important consideration when planning clinical trials with IL-5 antagonists.

\section{Hypereosinophilic syndrome}

Hypereosinophilic syndrome (HES) is a heterogeneous group of disorders characterized by the presence of unexplained eosinophilia $\left(>1.5 \times 10^{9} / \mathrm{L}>1500 / \mathrm{mm}^{3}\right)$ resulting in end organ damage. Four patients with HES refractory to or intolerant of therapy with corticosteroids, hydroxyurea, and interferon- $\alpha$ were treated with a single injection of reslizumab ( $1 \mathrm{mg} / \mathrm{kg}$ intravenously). Two patients responded to treatment with reslizumab, exhibiting a rapid decrease in eosinophilia accompanied by marked improvement in their symptoms. These positive responses were prolonged, lasting for more than 30 days following the $\mathrm{mAb}$ infusion. However, there was a rebound in the peripheral eosinophil count in both subjects at 6 to 8 weeks after treatment compared to baseline, and a severe exacerbation of symptoms preceded by a rise in serum IL-5 detectable at 1 month after treatment. ${ }^{36}$ HES represents a very rare group of conditions making it difficult to recruit sufficient patient numbers to a given clinical trial even in the multicenter setting. 


\section{Conclusion}

The development of novel antiinflammatory asthma therapy based on targeting cytokines has proven to be for the most part disappointing, with the majority of biologics proving inadequate in the clinical setting in asthma, even though they were highly effective in animal models of asthma. The latter is most likely due to the artificially-induced airway inflammation in animal models, which is not a true representation of the wide spectrum of pathologies observed in asthmatic patients. To date, reslizumab has yet to be convincingly proven as an effective treatment for eosinophilic asthma, but the development of discriminatory biomarkers and genetic profiling may identify patients with particular subphenotypes of asthma, allowing therapy to be targeted to those most likely to exhibit beneficial effects.

\section{Disclosures}

The author reports no conflicts of interest in this work. The author received no assistance in the preparation of this manuscript and has not served as a consultant or has any other financial interests in association with any of the therapies discussed in this article.

\section{References}

1. Walsh GM. Antagonism of eosinophil accumulation in asthma. Recent Pat Inflamm Allergy Drug Discov. 2010;4(3):210-213.

2. Bousquet J, Chanez P, Lacoste JY, et al. Eosinophilic inflammation in asthma. N Engl J Med. 1990;323(15):1033-1039.

3. Nissim Ben Efraim AH, Levi-Schaffer F. Tissue remodeling and angiogenesis in asthma: the role of the eosinophil. Ther Adv Respir Dis. 2008;2(3):163-171.

4. Blanchard C, Rothenberg ME. Biology of the eosinophil. Adv Immunol. 2009; 101:81-121.

5. Walsh GM. Advances in the immunobiology of eosinophils and their role in disease. Crit Rev Clin Lab Sci. 1999;36(5):453-496.

6. Egan RW, Umland SP, Cuss FM, Chapman RW. Biology of interleukin-5 and its relevance to allergic disease. Allergy. 1996;51(2):71-81.

7. Molfino NA, Gossage D, Kolbeck R, Parker JM, Geba GP. Molecular and clinical rationale for therapeutic targeting of interleukin-5 and its receptor. Clin Exp Allergy. 2012;42(5):712-737.

8. Long AA. Monoclonal antibodies and other biologic agents in the treatment of asthma. MAbs. 2009;1(3):237-246.

9. Walsh GM. Novel cytokine-directed therapies for asthma. Discov Med. 2011;11(59):283-291.

10. Corren J. Inhibition of interleukin-5 for the treatment of eosinophilic diseases. Discov Med. 2012;13(71):305-312.

11. Leckie MJ, ten Brinke A, Khan J, et al. Effects of an interleukin-5 blocking monoclonal antibody on eosinophils, airway hyper-responsiveness, and the late asthmatic response. Lancet. 2000;356(9248):2144-2148.

12. Kips JC, O'Connor BJ, Langley SJ, et al. Effect of SCH55700, a humanized anti-human interleukin-5 antibody in severe persistent asthma: a pilot study. Am J Resp Crit Care Med. 2003;167(12);1655-1659.

13. Flood-Page PT, Menzies-Gow AN, Kay AB, Robinson DS. Eosinophil's role remains uncertain as anti-interleukin-5 only partially depletes numbers in asthmatic airway. Am J Respir Crit Care Med. 2003;167(2): 199-204.
14. Flood-Page P, Swenson C, Faiferman I, et al; for International Mepolizumab Study Group. A study to evaluate safety and efficacy of mepolizumab in patients with moderate persistent asthma. Am J Respir Crit Care Med. 2007;176(11):1062-1071.

15. O'Byrne PM. The demise of anti IL-5 for asthma, or not. Am J Respir Crit Care Med. 2007;176(11):1059-1060.

16. Rosenberg HF, Phipps S, Foster PS. Eosinophil trafficking in allergy and asthma. J Allergy Clin Immunol. 2007;119(6):1303-1310.

17. Haldar P, Brightling CE, Hargadon B, et al. Mepolizumab and exacerbations of refractory eosinophilic asthma. $N$ Engl J Med. 2009;360(10): 973-984.

18. Nair P, Pizzichini MM, Kjarsgaard M, et al. Mepolizumab for prednisonedependent asthma with sputum eosinophilia. $N$ Engl J Med. 2009; 360(10):985-993.

19. Cook WJ, Walter LJ, Murgolo NJ, et al. Structure and humanization of a rat monoclonal Fab to human interleukin-5. Protein Eng. 1995;9(7): 623-628.

20. Egan RW, Athwal D, Bodmer MW, et al. Effect of Sch 55700, a humanized monoclonal antibody to human interleukin-5, on eosinophilic responses and bronchial hyperreactivity. Arzneimittelforschung. 1999;49(9):779-790.

21. Walsh GM. Reslizumab, a humanized monoclonal anti-IL-5 mAb for the treatment of eosinophil-mediated inflammatory conditions. Curr Opin Mol Ther. 2009;11(3):329-336.

22. Egan RW, Athwahl D, Chou CC, et al. Inhibition of pulmonary eosinophilia and hyperreactivity by antibodies to interleukin-5. Int Arch Allergy Immunol. 1995;107(1-3):321-322.

23. Bateman ND, Shahi A, Feeley KM, Woolford TJ. Activated eosinophils in nasal polyps: a comparison of asthmatic and non-asthmatic patients. Clin Otolaryngol. 2005;30(3):221-225.

24. Castro M, Mathur S, Hargreave F, et al; for Res-5-0010 Study Group. Reslizumab for poorly controlled, eosinophilic asthma: a randomized, placebo-controlled study. Am J Respir Crit Care Med. 2011;184(10): $1125-1132$.

25. Wechsler ME, Fulkerson PC, Bochner BS, et al. Novel targeted therapies for eosinophilic disorders. J Allergy Clin Immunol. 2012;130(3): 563-571.

26. Liacouras CA, Furuta GT, Hirano I, et al. Eosinophilic esophagitis: updated consensus recommendations for children and adults. J Allergy Clin Immunol. 2011;128(1):3-20.

27. De Angelis P, Morino G, Pane A, et al. Eosinophilic esophagitis: management and pharmacotherapy. Expert Opin Pharmacother. 2008; 9(5):731-740

28. Blanchard C, Rothenberg ME. Basic pathogenesis of eosinophilic esophagitis. Gastrointest Endosc Clin N Am. 2008;18(1): 133-143, x.

29. Blanchard C, Stucke EM, Rodriguez-Jimenez B, et al. A striking local esophageal cytokine expression profile in eosinophilic esophagitis. J Allergy Clin Immunol. 2011;127(1):208-217.

30. Spergel JM, Rothenberg ME, Collins MH, et al. Reslizumab in children and adolescents with eosinophilic esophagitis: results of a doubleblind, randomized, placebo-controlled trial. J Allergy Clin Immunol. 2012;129(2):456-463.e1-3.

31. Blanchard C, Wang N, Stringer KF, et al. Eotaxin-3 and a uniquely conserved gene-expression profile in eosinophilic esophagitis. J Clin Invest. 2006;116(2):536-547.

32. Liu LY, Sedgwick JB, Bates ME, et al. Decreased expression of membrane IL-5 receptor alpha on human eosinophils: II. IL-5 downmodulates its receptor via a proteinase-mediated process. J Immunol. 2002;169(11):6459-6466.

33. Liu LY, Sedgwick JB, Bates ME, et al. Decreased expression of membrane IL-5 receptor alpha on human eosinophils: I. Loss of membrane IL-5 receptor alpha on airway eosinophils and increased soluble IL-5 receptor alpha in the airway after allergen challenge. $J$ Immunol. 2002;169(11):6452-6458 
34. Gevaert P, Bachert C, Holtappels G, et al. Enhanced soluble interleukin-5 receptor alpha expression in nasal polyposis. Allergy. 2003;58(5):371-379.

35. Gevaert P, Lang-Loidolt D, Lackner A, et al. Nasal IL-5 levels determine the response to anti-IL-5 treatment in patients with nasal polyps. J Allergy Clin Immunol. 2006;118(5):1133-1141.
36. Klion AD, Law MA, Noel P, Kim YJ, Haverty TP, Nutman TB. Safety and efficacy of the monoclonal anti-interleukin-5 antibody SCH55700 in the treatment of patients with hypereosinophilic syndrome. Blood. 2004;103(8):2939-2941.

\section{Publish your work in this journal}

Biologics: Targets \& Therapy is an international, peer-reviewed journal focusing on the patho-physiological rationale for and clinical application of Biologic agents in the management of autoimmune diseases, cancers or other pathologies where a molecular target can be identified. This journal is indexed on PubMed Central, CAS, EMBase, Scopus

\section{Dovepress}

and the Elsevier Bibliographic databases. The manuscript management system is completely online and includes a very quick and fair peerreview system, which is all easy to use. Visit http://www.dovepress. com/testimonials.php to read real quotes from published authors. 